\section{Center for Biologics Evaluation and Re-}

search. Access: http:/ www.fda gov/cber/.

This Web site is the place to go to see how the United States Food and Drug Administration (FDA) regulates biological products. The Center for Biologics Evaluation and Research (CBER) oversees the production of vaccines, blood products, and cellular and tissue-based products. Manufacturers of biologics, health professionals, and consumers will find helpful information on the CBER site, such as topics on blood, therapeutics, vaccines, cellular and gene therapy, allergenics, and tissues. The information about each topic is comprehensive and includes background, approval, and safery information. There are links to other relevant sites for more information. The pages have been updated within the last two years; most within the last year.

The site offers a search engine powered by Google. The CBER site map is the most useful link for finding out what is available on these pages. Clicking on one of the headings on the site map or the homepage brings you to an overview of the general topic and a sidebar of specific topics.

Researchers at all levels needing specific U.S. legal and regulatory information about biological products will find these pages essential. From the "Reading Room," for example, you can find links to all the documents on the CBER Web site that are available through the Freedom of Information Act. They are listed by document type, such as warning letters, recalls, guides, or safety information. Undergraduate and graduate students interested in the U.S. policy concerning biologics, which often include timely topics such as vaccines and gene therapy, can find useful historical and current information here.-Carol McCulley, Linfield College, cmccull@linfield.edu

\title{
EUROPARL: The European Parliament
}

On-Line. Access: http://www europarl. eu.int/home/default_en.htm/.

The European Parliament is the legislative assembly of the European Union (EU) and traces its origin to 1958, when it began as the Common Assembly. At first only a consultative body, its powers have grown and it now passes laws in partnership with the EU Council of Ministers. It consists of 626 representatives elected by direct universal suffrage, and its Web site is available in 20 different languages.

Users who want to browse the site can easily start with ei-

Many of the consumer and health professional information links lead to the same documents such as "Safety Information," "FDA Patient Safety News," or "Recalls." At the consumer link, however, you will find an FAQ section for background information and definitions of terms such as biologics which would be good for undergraduate students doing general research. The health professional section contains links to "Clinical Investigator Information" and "Healthcare Letters," which contains letters sent by the FDA to scientists, healthcare professionals and the biologics industry. These letters provide evidence of how the FDA's CBER arm works to regulate these products. Links to relevant regulations are included in the letters. ther the subject index or the site map, both of which can be selected from a drop-down menu. Part of the site is devoted to the organization of the Parliament itself, with information on its members, activities, sessions, and hearings, as well as a "Citizens' Portal" to facilitate communication between EU citizens/residents and Parliament. The most useful portion for students and faculty, however, should be the many primary documents that are available

To search for documents, use the "Search Guide" from the drop-down menu. Using the

Joni R. Roberts is associate university librarian for public services and collection development at Willamette University, e-mail: jroberts@willamette.edu, and Carol A. Drost is associate university librarian for technical services at Willamette University, e-mail: cdrost@willamette.edu 
"Search Guide," one can search by words or by specific categories of documents, such as parliamentary debates, committee reports, minutes of proceedings, and texts adopted, each of which has different searching features. Some categories allow full-text searching, while others can only be retrieved by date. Although some documents are directly accessible, others can be retrieved only by special request, in which case the user must fill out a request form and wait for the document to be transmitted to him or her. Some documents may be restricted.

Other useful information on the Europarl site is a page on human rights (both within and outside EU), as well as documents relating to the STOA Programme (Scientific and Technological Options Assessment). The Europarl Web site should be of particular interest to political science, government, and law school faculty and students. A comprehensive site search feature would be a welcome improvement.-John A. Drobnicki, York College/CUNY, drobnicki@ york.cuny.edu

Poynteronline. Access: http://www.poynter.

org/.

The Poynter Institute is a nonprofit teaching and research institution founded by Nelson professional journalists and journalism students. "Columns" includes media industry news; issues and commentary; weblogs; question and answer columns; design techniques; writing tips; "converged" journalism topics, and journalism ethics discussion. There is also a listing of eight major topic areas relevant to journalism that includes ethics, leadership, diversity, online news, television/radio, photojournalism, writing/editing, and design/graphics.

One of the things the site accomplishes very effectively is making a connection between the various diverse resources available on a specific topic. For example, the diversity link includes a section of "Related Resources" that includes tip sheets, a diversity bibliography, seminar information, the Poynter Ethics Journal, and previous stories that have dealt with ethics issues.

One of the real jewels of Poynteronline is the "Resource Center," which includes extensive bibliographies on a number of journalism and media topics, a "Links to the News" column that compiles diverse resources on vari ous subjects, and an extensive list of journalism Web links organized into a subject directory format. Unfortunately, the resource center link is not very visible on the homepage and could

Poynter, longtime publisher of the St. $\mathrm{Pe}$ tersburg Times and the founder and chairman of Congressional Quarterly Almanac. Poynter's vision for the institute was to advance the values of editorial independence and quality journalism by creat-

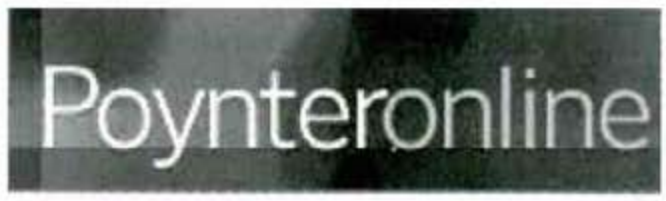
ing an organization that offers the journalism profession educational programs unavailable elsewhere. The Poynteronline Web site exists to support the mission of the institute by giving the reader "everything you need to be a better journalist."

One of the outstanding features of the site is a subject-specific search engine, NelsonSearch, that is "designed to tailor searches to those sites that are most likely to be useful to journalists." The engine crawls 221 newspaper and related sites, and searches can be customized to return results from specific beats, media types, or geographic regions. Journalism and media organization pages are also searchable, as are journalism schools, international and national news sites or television news sites.

There are a number of other resources on Poynteronline that would be useful to both

easily be overlooked. The site is well maintained and, due to the nature of the content, continuously updated. The columns, as well as much of the other information, are archived. A site map and site searching options are available. There are also opportunities for creating a personalized version of the page and for subscribing to e-mail newsletters.

Poynteronline, while generally fairly user friendly, tries to include too much information on the homepage, which results in a somewhat cluttered look. First-time users of the site might have to spend some time getting oriented before being able to navigate effectively through the wealth of information available.

Poynteronline is one of the more practical and useful sites on the Web for working journalists, student journalists, and journalism educators.-Patrick Reakes, University of Florida, pjr@mail.uflib.ufl.edu 